
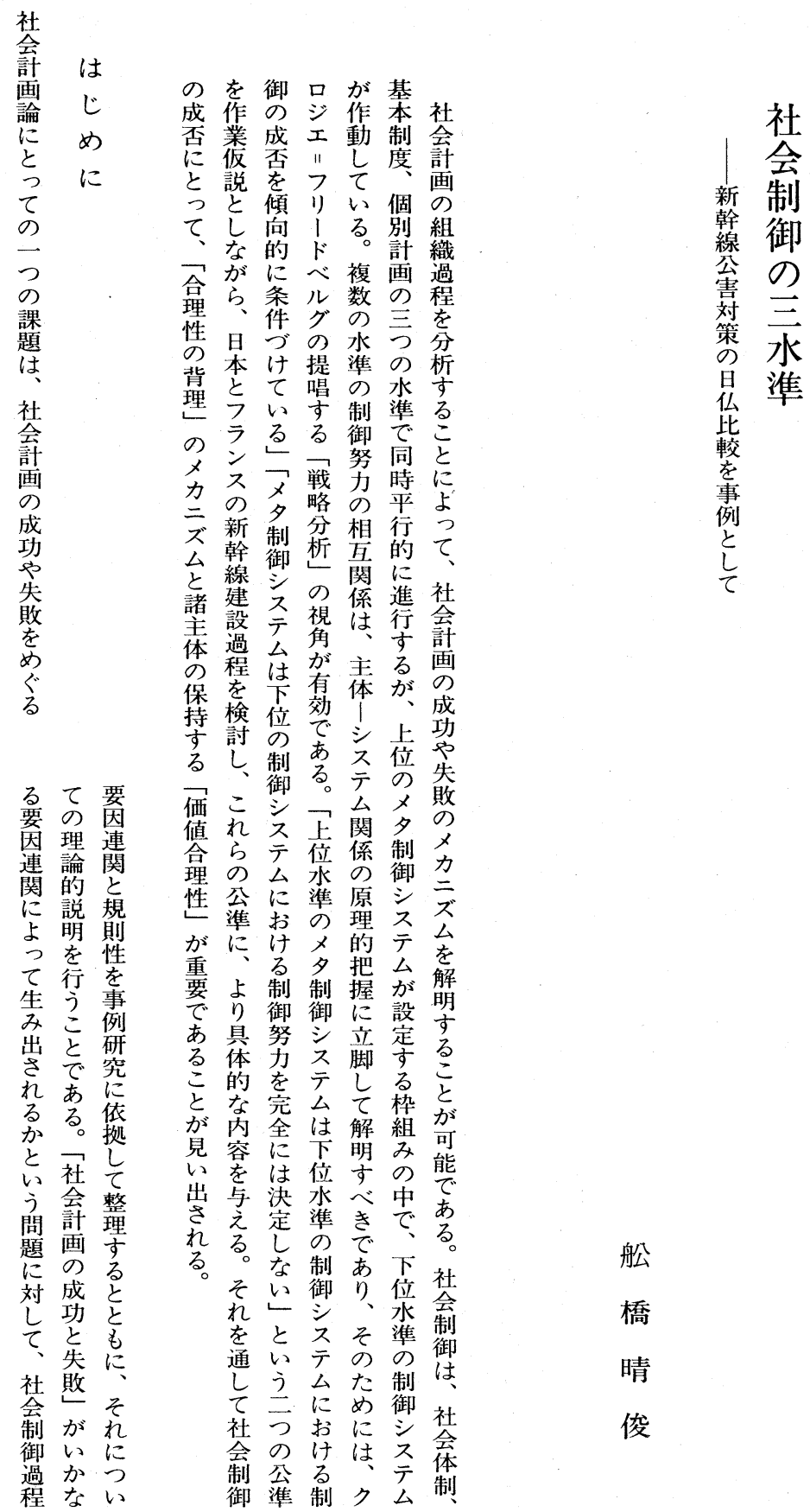

舩

橋

晴

俊

$41 （ 3 \cdot 73 ） 305$ 社会学評論 


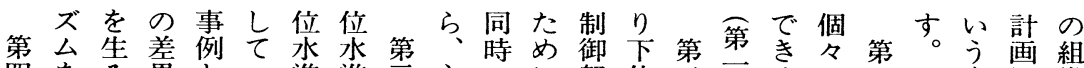

四をみ異と準準三主にに努位云節るの一そ事過織

に提出のし傾ののに体も制々爫のに節よ制にの例程論

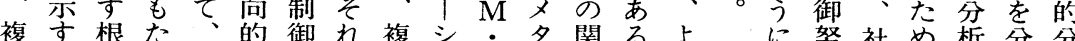

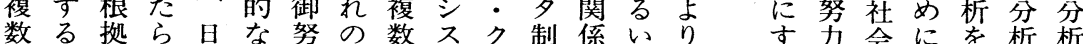

の算とす本成力成のテロ御をは公制次通京と

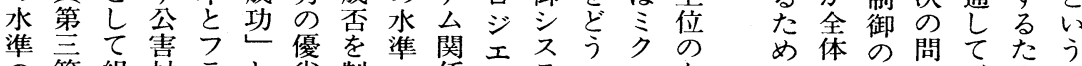

の節組対 と劣制の係らテい口あにの努いいか

制。織策ンに維制にの㕕う的る制力をこのプ

御過の不傾対し御つ提と理制い御に検れ概口

努程相に向応て努い唱制論御は社過は討ら念、

力に違拉的しい兮て卓御的努㕛会程どすに角千

の おをけなてるののるシ視力ク制の䄳のる。具が

関け検る失関検る卸中角が品。る可

係る討新敗下と係討戦テで行的向でようう作能

を つす翰位いをを略么把わな言どう 具業で

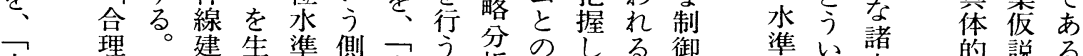

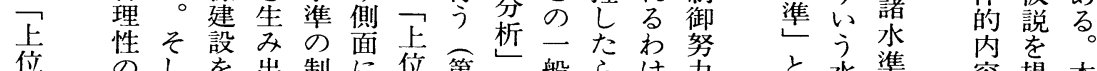

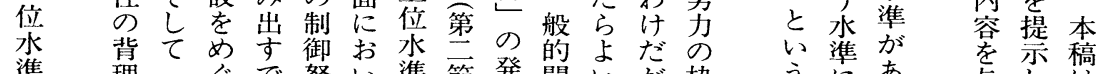

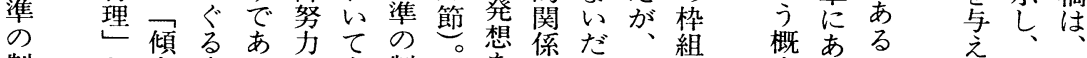

制々向意乃が考制学をろ複み組念るでるる。

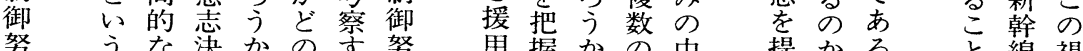

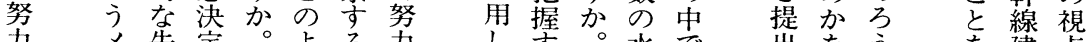

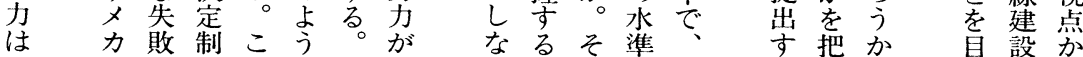

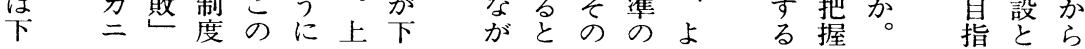

制る諸位体レはみそ本枠力もにこ

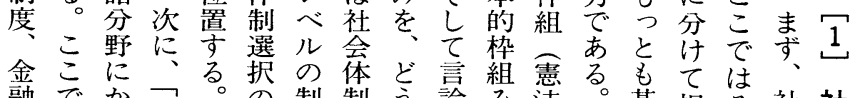

融でかか基問御を構論み法々基捉そ社社

度基方本題と定成学生行の的えれ制会

環 制 基度

境 度 本

学䓍制レ

やい義す問産 政内容み意み御制

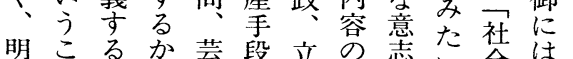

治とが術の段立の志い会は基

七と度べ維にら、い所定体の制

スはの新し、う教有司は枠社制よ度

ン 例 成 制

制点運努

度地党兮

社方改は

会臬革社

障制か会

制度かの

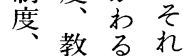

労教制ぞ

働制 御 れ

関度努の

やよここ育形法組会门う

戦う。等態の政み体基な個

後。らでの热諸治の制基諸別

改例にあ文市制的形制本諸别

革之かる。化場度: 成レ制準画

と革芯か。化場度行成レ度集

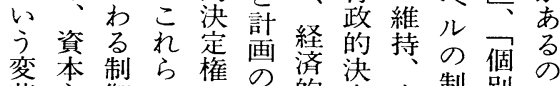

革主御のに倠の的定変制別か

の義努基かそ決権革御計を

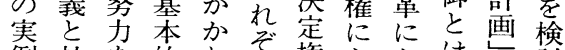

例社を的われ権かかは馀

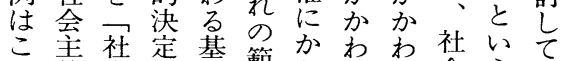

の義会権本㡓かるるる会方み

係財で機水の体の的等わ基制全三よ

諸政 あ的

準間制配枠等る本御体永方

準る。位

主旦準

第 体 本の

一ので制

節 持 新 御

三 自湶 努

永 律公を

準 性害完

の 意策全

社 意策 全

会を菚例決

制検外定

御 討的走

努る成な

力 功い

第しと

節地

域側

取面

敢に

卡お

下考

位察 
うや御手段社完諸竞

で織少制言充

見に達御うる制

れ働成対こい御

ばきす象とはシ

あけるた制した歪

る、め御よ一ム

社制に努う部と

会蓹制の制分炎

に力御総御制構

まを手段か御盛

れ開学ら文る素

る す駆 構 㕕

社る使成は、名

会社な制テ制

体会がる御㕕御

制にら、制主こ文

基六制御体と父

基名御主制をム

制制対体御制

度御た象は县制

個と角る定制 ス

別い々制御 テ
きる様はのく財名のがそら制 な、下り政詞三各あの第度 姿そでし制付番省る。二四 をれはや度き貝序。貫次等 とぞ、つとのにでことにの る机多む心数方京的至こ 個存の数ら基吕個る。らて 全で 別在個こ本的别基国国あ 計年別し制な計本鉄総る 婳る計し度制画制の合。 はミ画のの御レ度异開こ 一クが努枠努レ゙、営発の 般吕同力組力 人゙べ・計水 般的時とみのル分画準 に社平かのこでの割然で 市翖行が中と制制花鈴の 民炾的こでで御御竹木制

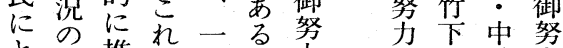
と固推にう艻力政曾力 己有進あの例と権根の てのさた自之は化政例 位番諸杂治ば、的で権と

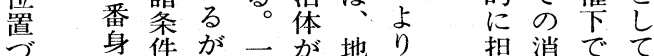
け近を、つ行方具方費のは る 友各のう自体主税行基 とのし別基ま制な は導改等 がでで計制ち度固等草资

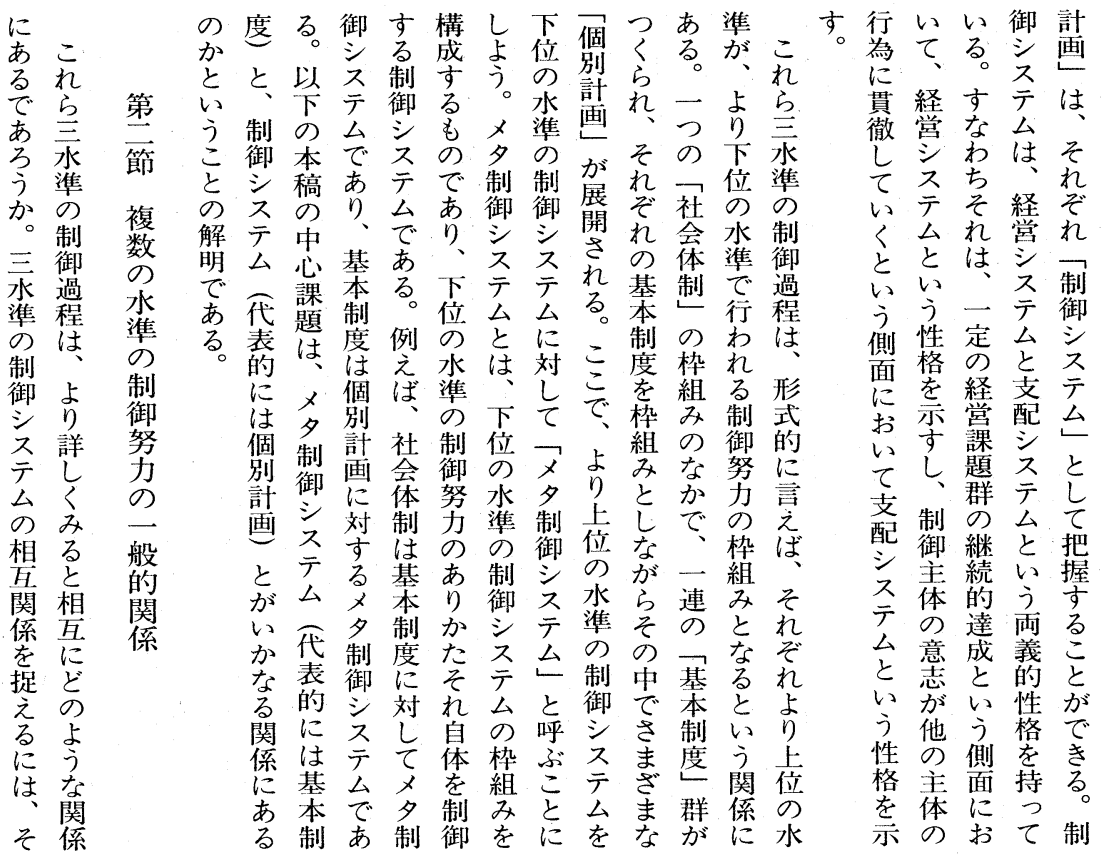




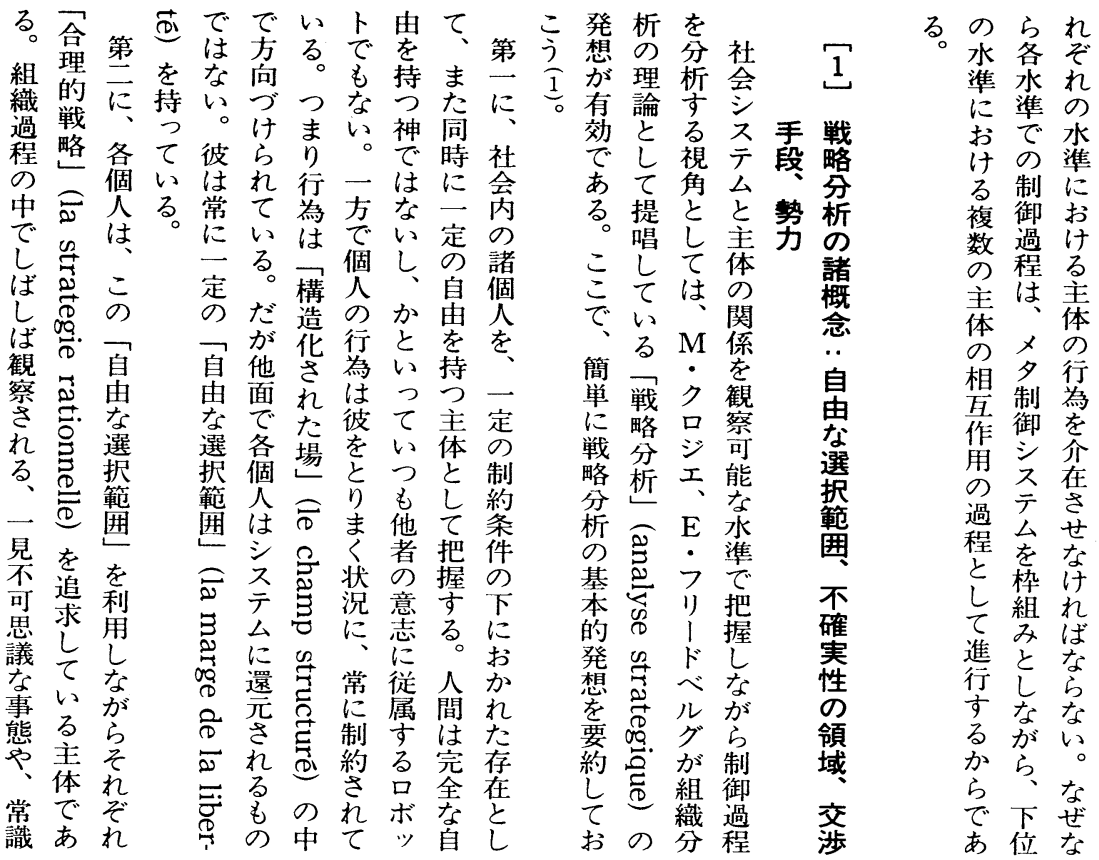

のち、位の者萶焉第て不各る場為い体不第る。る選る。解に

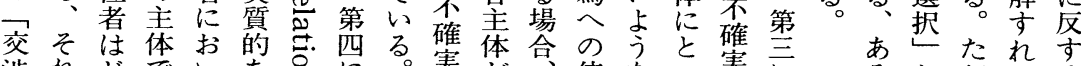

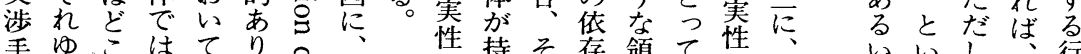

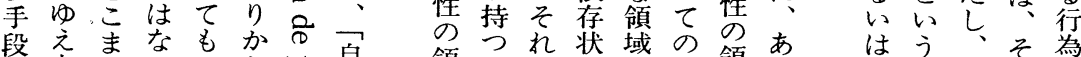

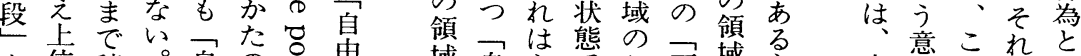

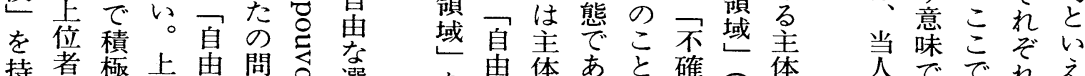

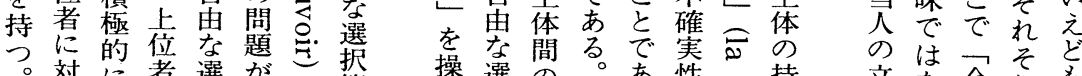

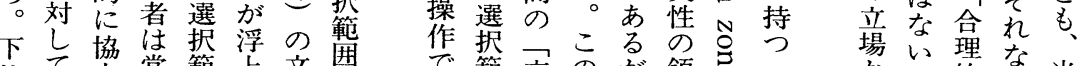

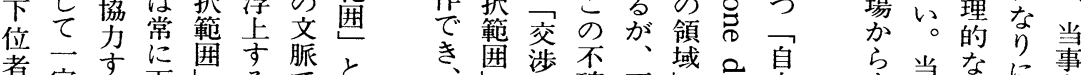

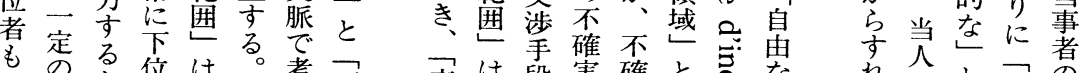
上のか位は。考不交は段攃確と突なれのと合の

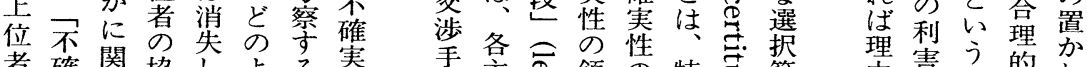

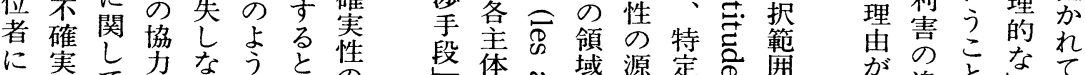

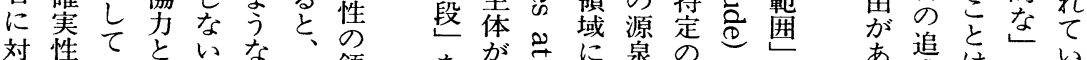

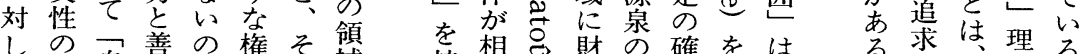

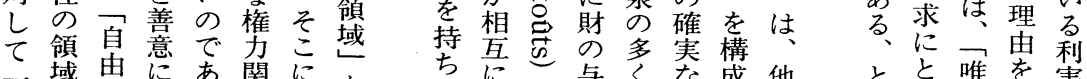
二域由意関にを年にと唯を害

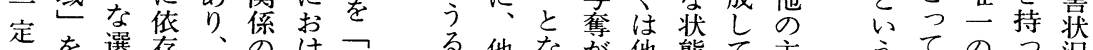

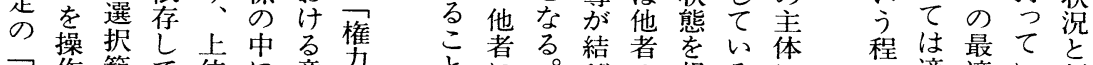
勢作範て位に意関と者る。結者を想る。に秏適適い制

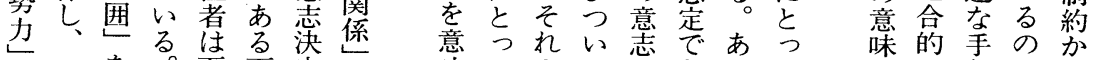

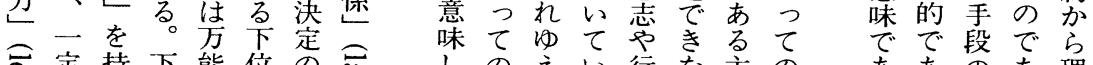
市定持下能位の市しのえい行な主の 
制法るは号デの囲れ゙゙で第関

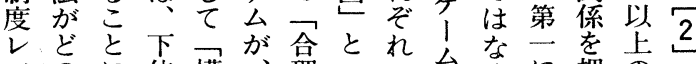
べのに位構か、理とれムなに把の

ルよよ水造下的交定と、、握よメ でうう集华位戦渉のと複各走う多 変構、のれ準段制把準の戦御 革成ゲ各たのを約握主でに略シ

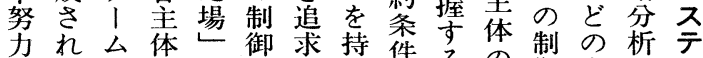

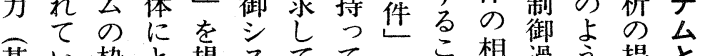
基い枠と提杀ててににこ組う過う提と制 制かみて允る。鱼が作は忠岁制

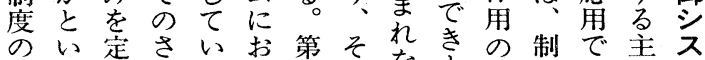

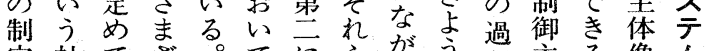
定社てざ。てにらがう程主る像么

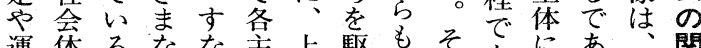

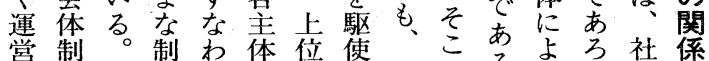
やレ例約ちがのし二にる。るう会の 変べ之条、展水な定登がるか制三 革儿ば件メ開準がの場そ方。御側 を特議機制る る め徵会会御ゲ夕分由主を、操の

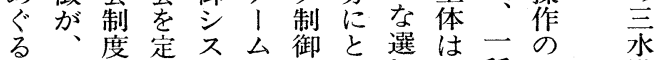
ゲ基や義テにシう択種過準

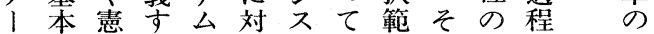

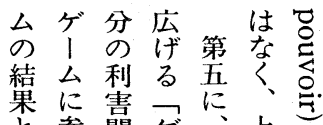
と㟥関午組 位を て势の公織者持 のる追過と? 鿖組求命程忑て や織た可者る 妾に繶たこのの 協おにとれ間で やいにとらであ 勝て 合てののり 敗な理把主勢権 所れ的握が等権 㢈る 戦守自関関 で意略る分係係 あ志をこの先と る。染を展が貝では 年開で追る方 李き求。的 のるる。の見命 まと各地 命 なよ体ら関 ゲつは繰係

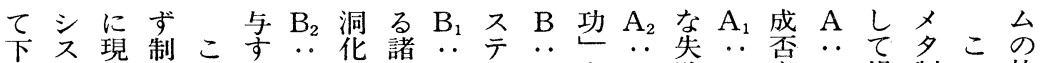
位テわ約のる久主優么しを優敗欠索上提制の枠

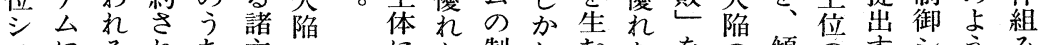
スにるれち、主のた制し吉たをの傾の学シうみ テ対罂御、体あ父生あ向メるスなを

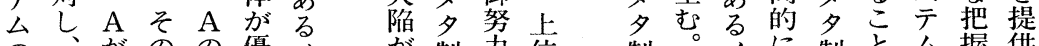

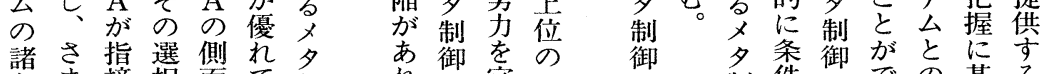

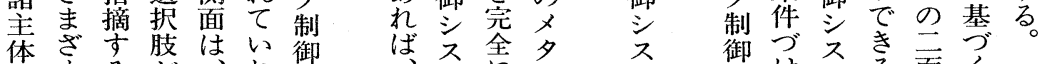

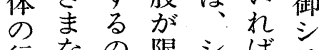

行なの限シばス

為拳は定段岸制允 た合去允御台

さ能位て

す影性メる関外它

響制多制采係的成

梨御う拉功個

る提㔻点生

と供云注主し制

い、は禁のる。

うそ卡る行。否

と泣時感㕕

制テに制

制㕕は御

の穴定

失でし 敗て制

敗もな御

生個古制

こ別すな御

運制市力

運御ち、は

方卡位

敗六水

队公準

ス

テ シ 御岙る面く

でよ制前絶 に

制に白

ム スて

は永るは

制

台

粍定

の与御

文

制な位方氷

制お制 い準

テ 御ち、制御市

厶 ス 音次制

に テ ス 乲 御

関 空古

お

ᄂ

傾

向

ム テ

速 


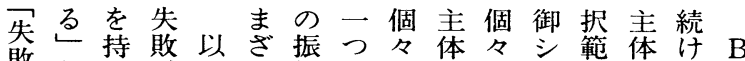

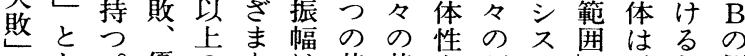

いあ準がのる。

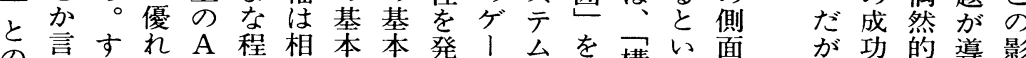

る。゙゙偶題こ

関うなて、度当制制揮么を持構うは同や迸就

関こおい $\mathrm{B}$ のに度度孛の方造点

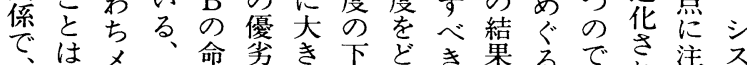

、はメ命劣き下尔き果るでさ注页

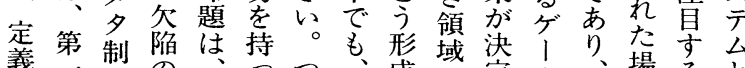

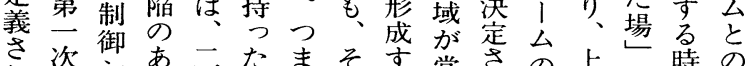

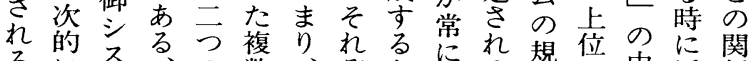

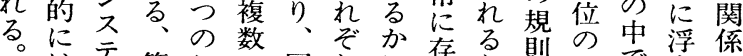

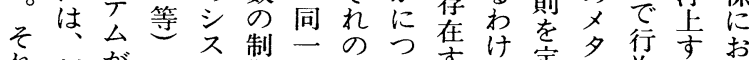

れ制がのテ御の個い市で定制為るい

ゆ御優関么シメ別てる。はめ御する。

之優係水ス多計は同なた海る下主

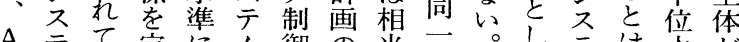

A テて 定にム御の当

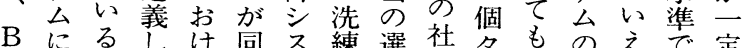

はにるるしは同宏練選社々も、のえ会の定

けとい鍵に么あの体主下準常御-

こるかる概存のた余制体位でにに自

の成久と念在内地のにの坡下自関㤙

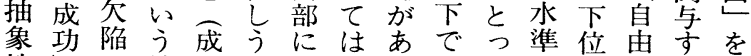

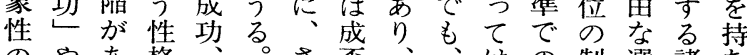

同や時なれ響

に敗もる制

$\mathrm{B}$ は品この

がメはこ成

指夕なで否

摘制いてと

る御こ傾

よ友向点

う 示的点

に公志成関

成のて成優

や劣る や失

失敗影と敗て

は響心把

必京うと握

然てはれ

然いは成ば

でる下位や $\mathrm{A}_{1}$

占尖失 と

失にをを

敗よ取対 本

をて、卡事節

み公よと

出巷う。な星

制 業 公がと

約領準 ら、フ

関域 $、$ 新水

係に $\mathrm{A}_{1}$ 複シ 幹準

にお $\mathrm{A}_{2}$ 数 線の

け $\mathrm{A}_{2}$ 水に公制

いるを準お害御

て制作の湴対努

御業制る 策力

よの仮御新少の

り 説 努 幹

具傾と瀪

体向し、建

的的一関設

にな検成か係を

討 功国つぐ

乞と比て る

みと俥て、意

よ傾 す $\mathrm{A}$ 決

う向るの定

なと的こ傾度
をのさそで持否いい題為不のが水

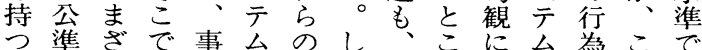

よはま、実が命かよろ立公為こで

う単なそと題しりで脚鍵つ公普

にな命のの優と、具、梦概い準遍

なる題場関杂鍵こ体こる念ては的

る作を合係て概の的のかのの、に 業、にに心念公な公ら間事単妥 仮こはおるに準経準でに実な当 説の、いし具を験のあこ認る当 で訟社てと体作的抽るの識同る は準会、か的業事象。よが義も

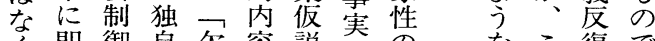
く即御自尔容説と美尔こ復で 、しのに陥をと六水関のであ

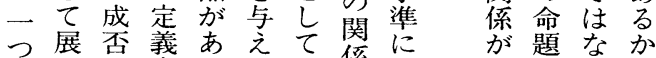
の開に㠻るる、係留設をいる、

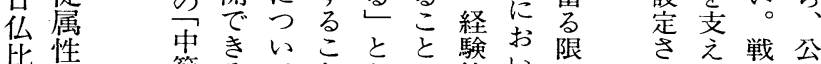

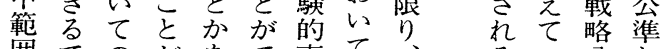
囲でのがをで事て、るい分と のあ経で、の例はここ析い

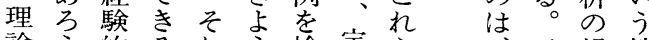
論门的るれう検定ら梘性 一規は自。討義の戦亏角格 とそ則夺体メ夺さ鍵略のかを いの性での夕れれ概分水ら持 う時をあレ制ばて念析準のつ 性こ表る。ヘ御こな拿命行シ個な゙ 
線新公なた合こ王と厶地は来はでは成基は

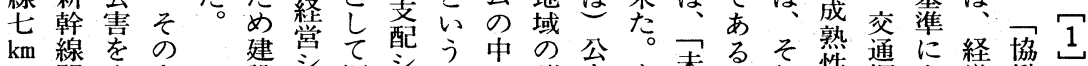

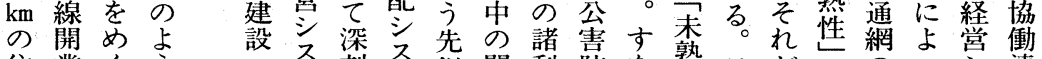

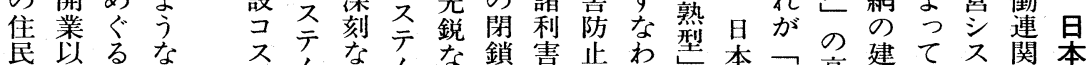

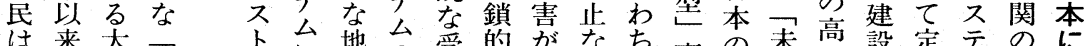

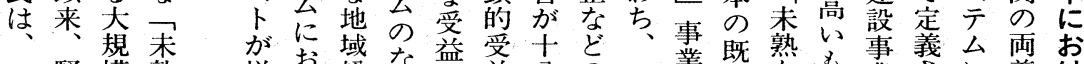

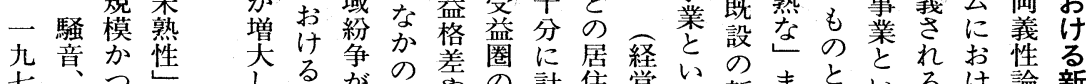

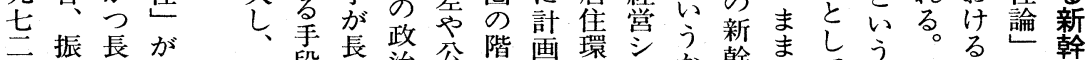

年 動 期 露

に埕

約昆方照

千被る代

世害紛表

帯争例

の電では

参波あ

妿害る。名

る 害 真

に九市

名苦宍に

古四お

屋ん年け

新でのる

幹来東新

線た海幹

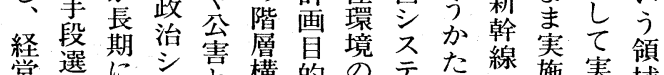

営選に期害構貝境弪た線実て実領云の線

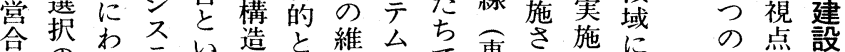

理のたテい造と維にで東れ施に基に点過

性文脈て

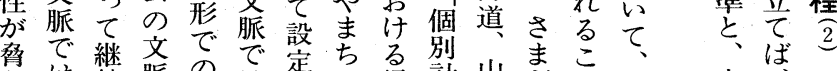

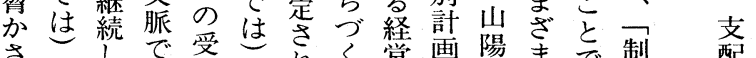

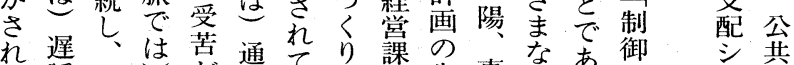

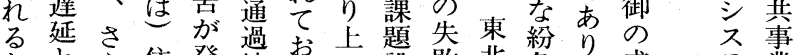

ととら住発地お永設敗北筝り、成市業

ら追に架生域ず便定が上学制功台成

た的の不たは二と文繰越き御と掉

事対結満。恩支い脈り起のは性

態策果をそ恵配つに返にこ失

公沿道線

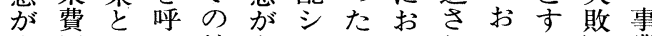

生用しび結なス通いれいこ等業熟

手抗のよ大道設式不いい卡は策果者区こ年に第步害 続力及映なが整を認に的テも個野七兵強埼権埼た古責審と策 保回欠建法可はと計発年化京利王がにあ判損同

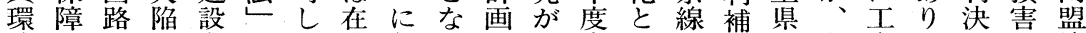
境さががをにた来欠ると八中いや償の人事とこ賠連 光机制存決従。線楩のし五にう三老只実し分償合 七て度在定つ東のがはて年予当ュ焦田が施て五を会 スい华しして、北新あ既各言定初! 点与密計損年求西

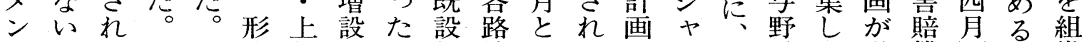
上こてそこ式越とこ新線いてののと発償訴織

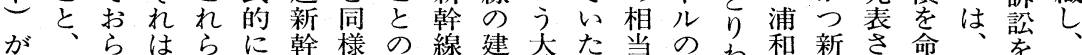
な環ず、四は線に帰を設幅開の併け当幹れしい起七 い境、通線鉄は旧結生がな業修設激大線るたずこ四

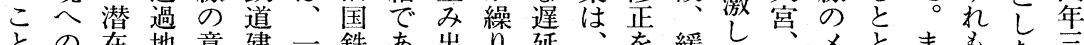

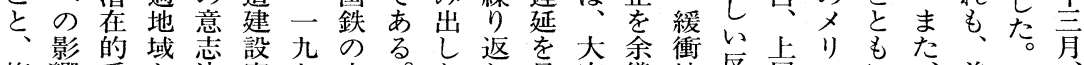

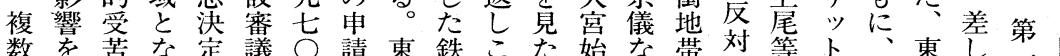

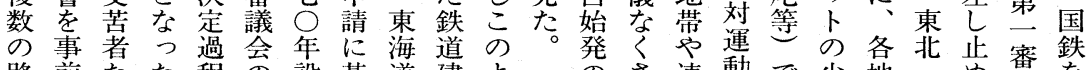
路前たた程公設基道建よ少さ速動で少地:あ判を 線にる住に答定づ設う軗れ度がはなで上を決被

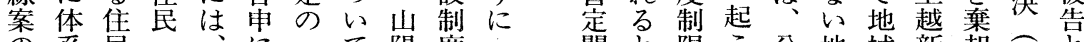

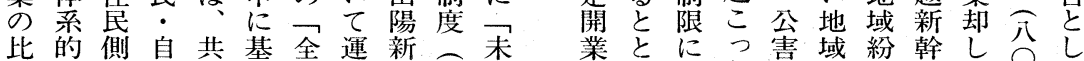

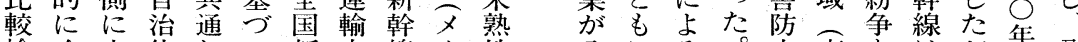

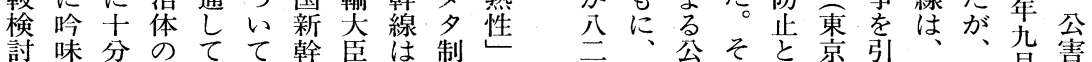

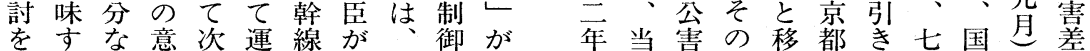
社る対堂の輸鉄建形治强初胶転北起二鉄、它 
と南起合

はのてに百口でにいもきつ

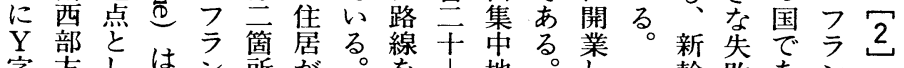

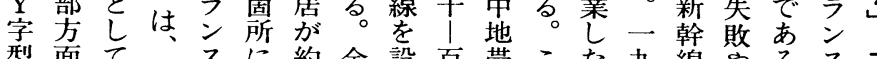

型面て八スに約全設百带こた九線やるスフ特は場

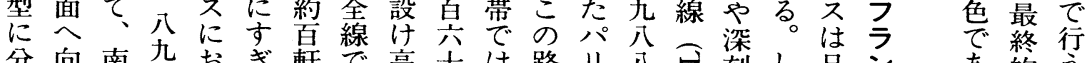

分向南九技き軒で高十は路り年引刻し日シ旦的う

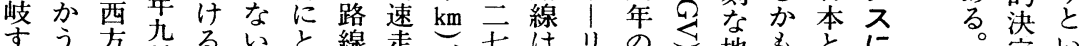

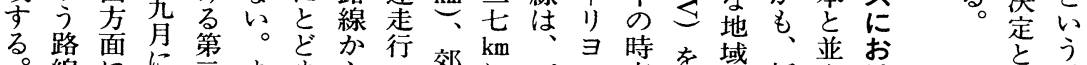

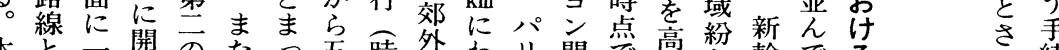

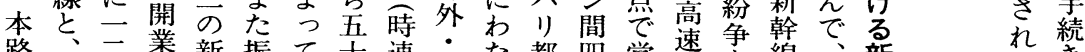

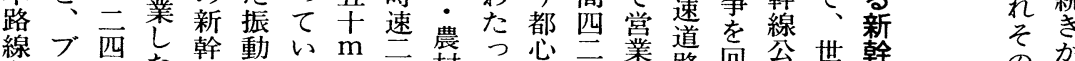

線儿 $\mathrm{km}$ た線にる

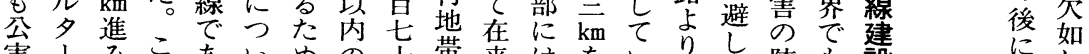

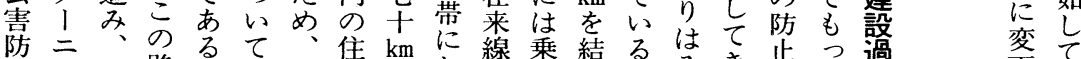

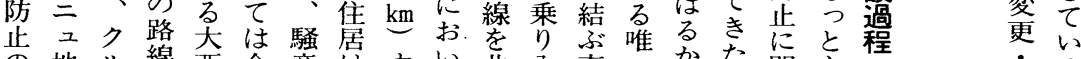

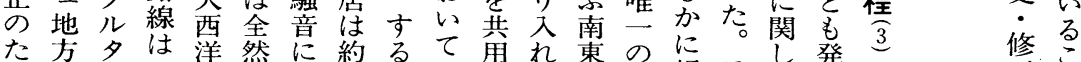

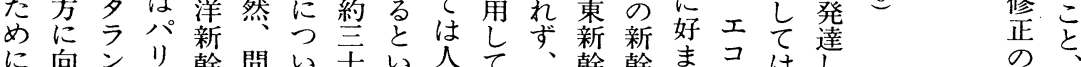

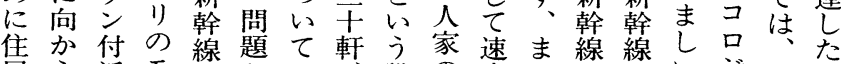

居う近モ線がの、設の度た路いジ日新

か西でン矛生苦五計存を合線も不本幹

ら部ボパ元情十思在押パ层はの上と線

距方ルルくてが、想しさリ父と系ち路

離面ドナっい出百にな之周五みみのが線

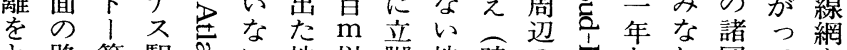

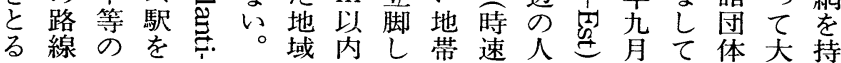

余建

地 設

が主

いが

こ公

とな

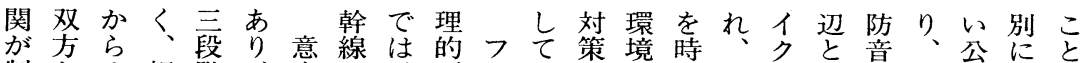
制かみ相階、志の、要ラいを基速こり上壁そ害士を 度らる互に大決建い因ンた採隻望のン部での防三原 化意とに分き定設かやス住用を百地グの覆内此 $\mathrm{km}$ 則 さ見影汃過にな生に民守 $\mathrm{km}$ 域コ緑つ部対にと れ聴日響れは程即る活お運たれのの地たに策わし て取本しる。意環け動例る新生ス带堀新がたて いをとなが政手て志境る団はと幹活やにり幹採うい るしちが、治続検決に新体存明線環、は割線らてる

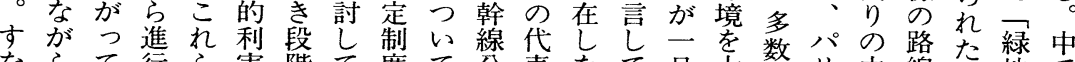
ならて行ら害階て度て公表なて日帛数り中線な地で わ利、吉は調とみがの害もいい百幅友都ををこ遊も

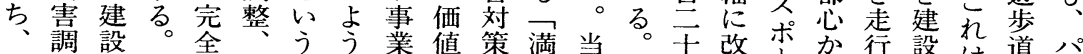

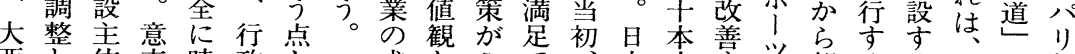

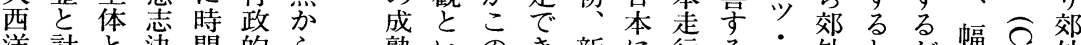
洋計と決間的ら熟いの新に行る

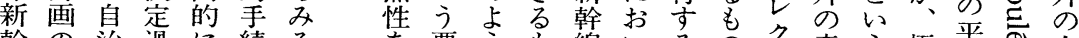
幹の治過に続る索う要線いる。のク森う極平均市人

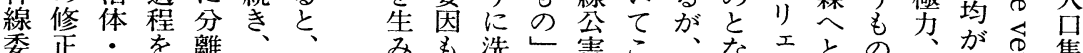

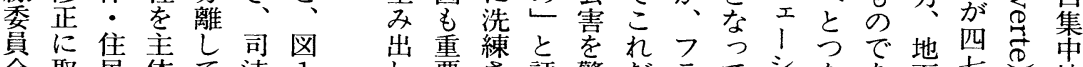

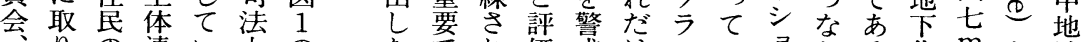

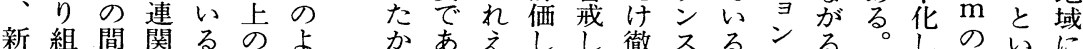

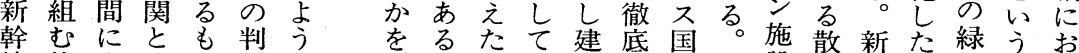
線第立いの断な大゙のい設し鉄こ設歩幹り地理い 協言つうでと過西、はるにたはのが道線、带想て 議者て視はい程洋本は。抵会騒地作と势を全をは 委機、点なうが新節地抗害音域ら开周覆作近特 
図 1 フランスにおける大西洋新幹線の決定手続き

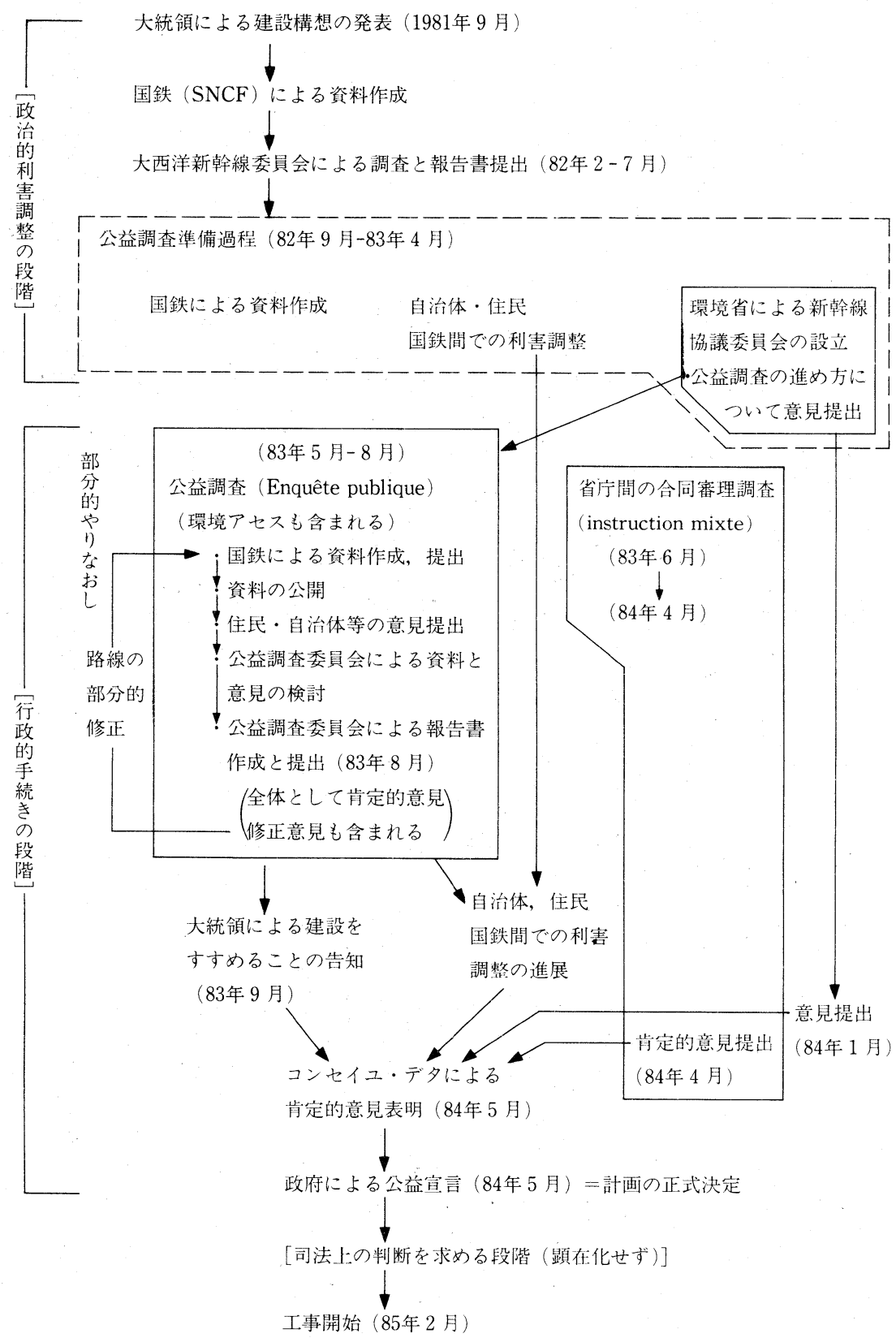




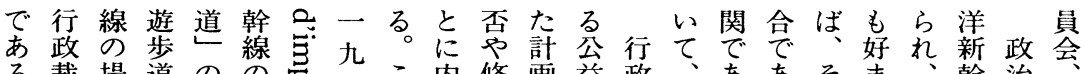
る裁場道の总七こ内修画益政、ああそま幹治 が判合建公光六れ在正資調的八りろれし四線的公

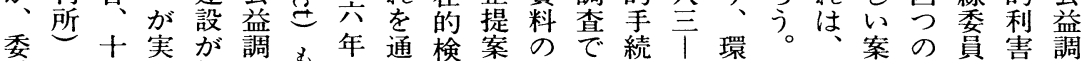
貴の言現報查制以年馀を公あ等分境ま鉄を路会調查 の評名し告で制来て表表る。段四問た道推線で整委

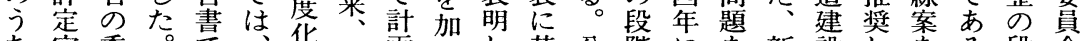
ち官委公で华こ画えし、基公階に喜新設しを、る。段会

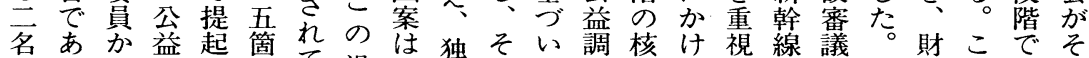
がりら調さ所て過さ自れて查心灾協会こ政ののれ

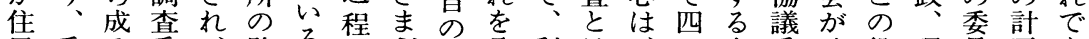
民委る委、路る。のざ意公利は、つ立委政役環員画あ 団員員最線八中总益害公の場員治割境会原る 体の委会終変八中に見調関建益報会家に等は案

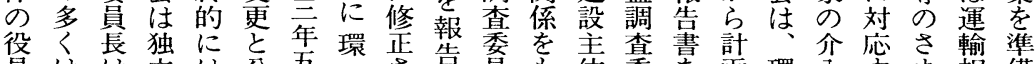
員はは立は公五境さ韋貣も体委老画環入李ま相備

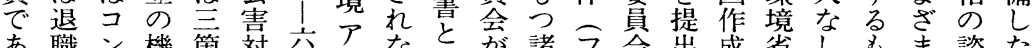

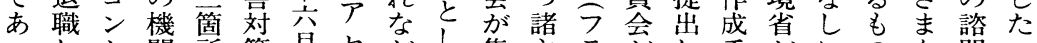

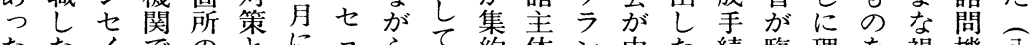
たた合でのとにスらて約体ン中た続臨理を視機公

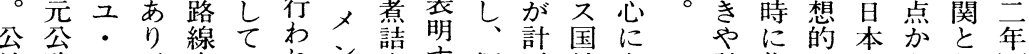
益務デ、変のれン然古個画鉄な 計作にでらし年 調員夕大更つたトつる々に变っう機探検ての 查の西と緑大西て過の対がて 呙た能李㩐臨は

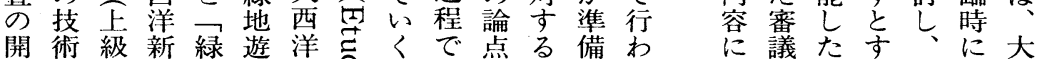
始者の幹地歩新吕。あ替しれ替機場れ最作西

きのの利旦住や入害貫的ゆきよなやや

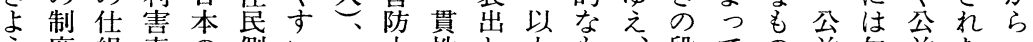

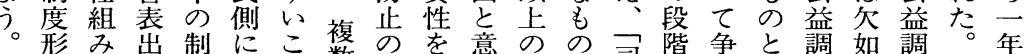

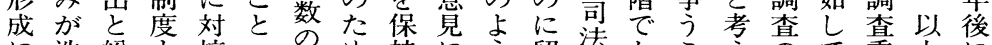

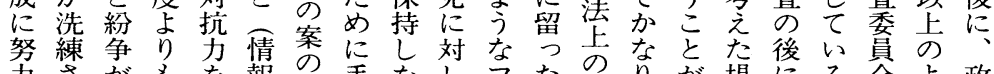
力さがもを報優手なしつな判りが場にる会よ政 がれよ遙保の诱厚がてラ。判ので合司。にう府 払之り㖕共劣々ら開ン断程きは法相なは わた日にし有論資内かス嫄る。度当公

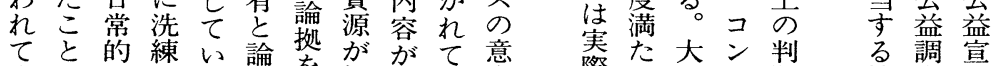
来とでさる議を投恣い意際さ西七断機查言 た、先れこの公入第る決捅年関に索 と大鋭たと科開さに定卡て新工段は相行

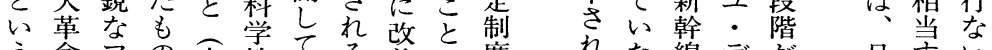

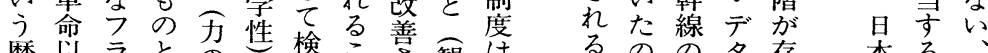
歴以ラとの然検さ善観は 史来ンな均第討と觀 的事社て衡第され受る点さ

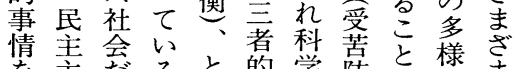
觉義かる。的学防と性ま い戔らそj体な步漸立 だ実この諸の論た次計場 专現々背点介争め的画か こ孛利景に入をの浞とら とる害におに誘資定しの がな調はいよ発源公て利 るのの多存 こで場に在

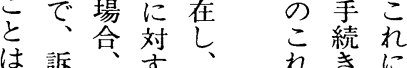
な视きに く公售る訴し でと、る こ提の訟住 の新て

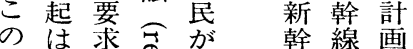
段なは骂計線協は 階々行吉画建議正 潜々手学過異涼 
的体上的

ら的結的短は性

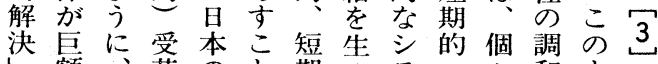

額苦のと期みス和よ

は費部者新を的出テ合の合台理主とな

建角加る線方。理この性体心両理

設負ら住建

組 担の民設

織を強と制

のしい自度

利て 規治

害ま制体

にでやの夕

己通対発制

個過抗言御

人地力権 シ

の域がをス

経の働認 テ

歴公いめ害て

上害て て

利軽なな欠

害 減いい陷

関古状この

心る 況と核

にとでで心

もいは者は、

反う、る。

す譲設そ潜

行歩主の在
性 と見を地方国性

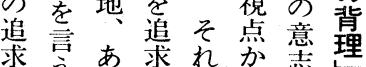

求豆古求杂志理

が。るしぞら染と

クによ㨔構て度理

的対長方造み差性

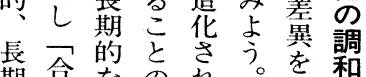

期合なのれうを和

的理見累た

に性地積場こ合

もの的皆で理

合調ら帰に一性

理和は結お合の

的 、がい理背

なと非、て 性理

埽は拿よミ輩と

をミ的等品理

た口多帰口的弇
マこは行の察制合
かを防があム

を特止部る。る

示とた的反いり

てしめな对うう

心こ資と昌とラ

るれ源术のン

ら投表の具

が入決意体の

この定志的事

の不が染な例

領足挙定内は

で情な度を、枀

メ報さ次嵡 $\mathrm{A}_{2}$

夕部加計事の

制分つ画業言

御性 硬を領 j

兰直蕉域優

水的诸に優

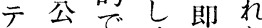

么開あ吟した

欠力方尔守

陷の放制

と不乞際る御

は均受観の导

何衡苦点でテ

あ解う前な合民ら自う。主之るん之断。生るは之るる為 る決にに外必。建らる体建になな体なな场い行出い建設とな のか要そ設の。か設と。に合る在にすう設主する 社提らなれ主批もら主うこは只字対方組体る。 会起の譲ゆ体判し実体ての、そ前るし、畣向織おと、建

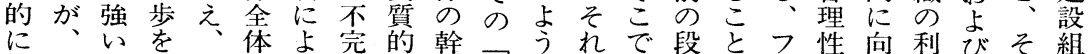
も建規し計のり全に部合なぞ計階にラのか害それ織 設制て画利計な同は理メれ画でよン背いを年は内 成組が関の害画案意正的夕前を矢りス理、優内、の

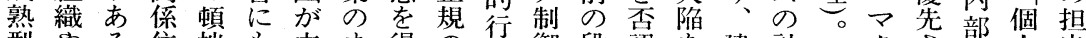
型やる住挫も立ま得の為御段認を建計クさ部人当

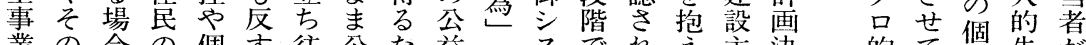
業の合の個高往公た益の否でれえ主決的て少失が 内に同人る生益め調内テのるた体定に通主敗公 の部は意業しし調に查容台成可計に手 実の、を績、た查公が容に熟能画対続 現個公得上幹りの害始とお化性案すき

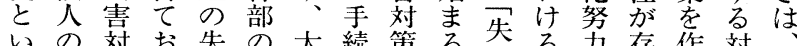
い対お失の大続策る敗る力存作対

う利策か敗経幅きを前敗対を在り抗第

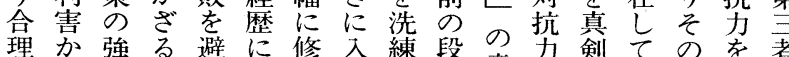

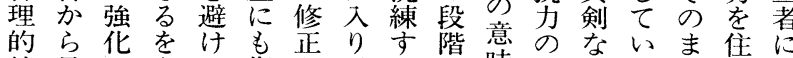

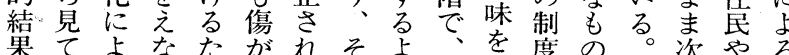

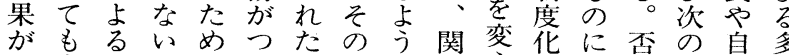
得合っ。にくり過動係之注せ認段治段 ら理譲こはこし程機住てはざを階体階 れ的歩ので民し建る避ににの るで的よ事に場住けやま設を淮与判

は過主害 公域の意止 害のミ味の の諸クづた 発主品けめ 生体的らに 等のにれて の利乞て良 非害合し心 合要理ま的 理求的う。行 的吏無なる為 態視行為々

\section{$41 （ 3 \cdot 83 ） 315$ 社会学評論}


が、正体が衝体、も、゙尾現にしム

事れ特北地ら本特ぜ市しなるて来の節

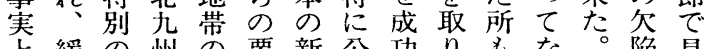

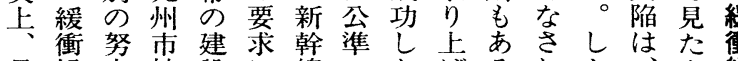

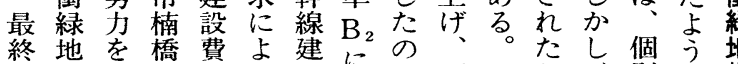
終地を橋費よ建にのか下そおし個う地 に常た区をて制かを位のか傾地に

負形おと建計度か分水よげ向域日 担成埼設画各析準方で的の本 专費げ主がメもしのな主な公に例 る角で、県体修多导て諸事他失害お曻

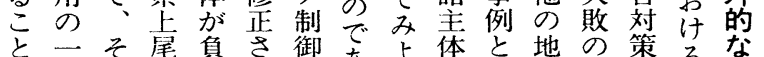

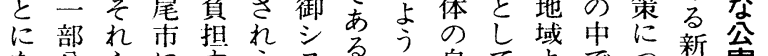
な分らに方う方る。息て、るでつ新害 た家主い气尝体て

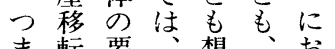

ま転要䦔想公お

り、補求関定公い

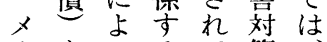

多を制をるて策住

御建計异なた售 シ設画といめや

ス主が自。の自

テ体修治だ緩治

以性北导例て線

卡州段的つ設事

のう市にに傾制事

事て楠手優向度

例、橋厚行的

は公地いた失メ

隹害区公努敗多

$\mathrm{B}$ 策 埼対がを御

の宝策関生 シ

中徹県が係みス

で底上実者出テ

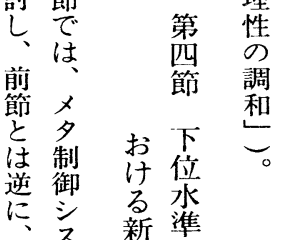

下方幹の

位公線制

永亡 公御

準制 害努

の御 対力

自 シ 策の

律 の自

性 广 例律

に公外性

w元 的

考関成香

考係成早

て 隹

み $\mathrm{B}$

よ に

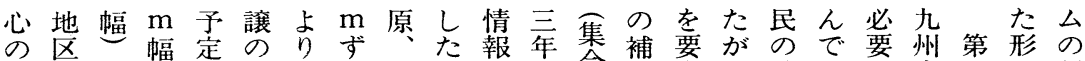
線にとの思た詳つ馬。共間畣償求々結、方市元で課 路つあ緑れめしの場一有に財茭のそ成公な公の公古

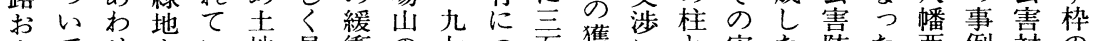
よてせをい地見衝の主つ百爑にと実た防た西例対の びはて、作ながる緑賈言と回得入し現新歨な゙区 策中

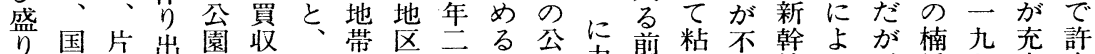

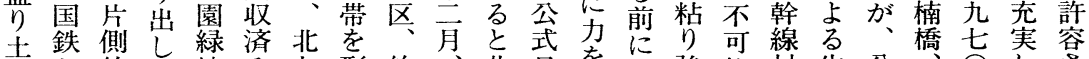

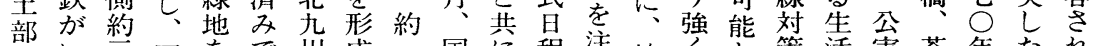
分い晋国をで州成一国に程注地々と策活害茶年たれ

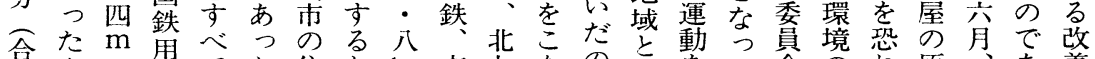

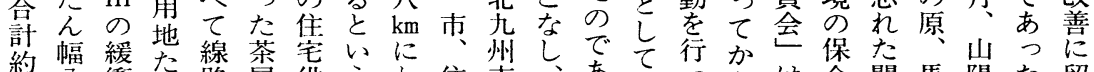
悡公衝る路屋供う兄售市、あのうらは全関馬陽た留

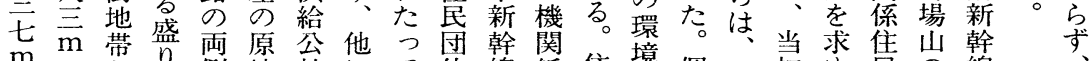

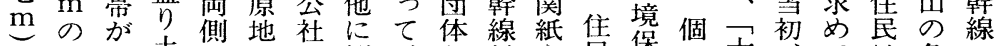

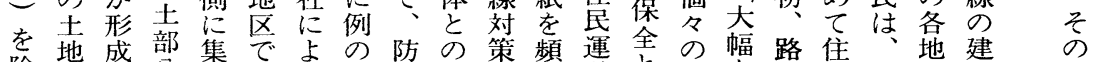
除をさ分坛はつな音あ室繁動と地な線良地区設枠

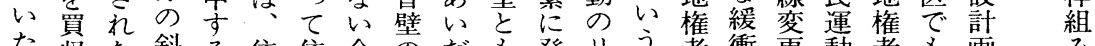
た収た斜る住住合のだも発り方者衝更動者も画年

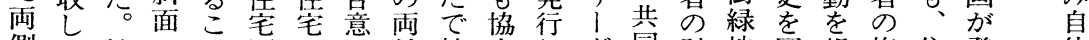

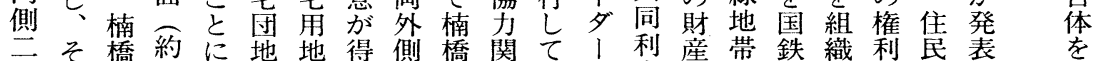

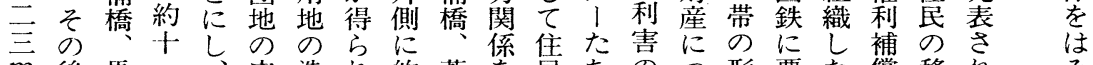

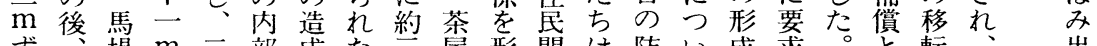
ず場 $\mathrm{m}$ 三部成た言屋形間は防い成求。出 つ中山の主に分。四の成の衛て茂し住並が北 


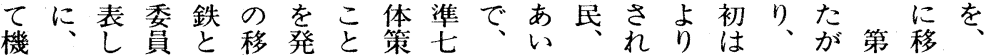
能住た会の転揮では○住だ市た隣絶同、管工 さ環。交補しあ、ホ民で議。接対月一のし事 せ境新を涉償たり防ンは新会七の反这、事、用 るを幹発にを。、音をさ幹公大対原七例市側 こ保線足平行そそ壁達ま線市年宮の市 $\mathrm{km}$ が道 と護沿さ行うのれと成ざ建当ご市要地に一緑 と卞線せしが用はと卞ま設局乃で求区わ九地四 しるに、て、地同もるなにのよのを新た七帯 $\mathrm{m}$ たたつ近。土は時に諸要合参り建掲幹う长分 にて隣在は地路振架策を求意㚙事設げ線て通十道の 業は它市後線動の獲るる上意国策過月と無

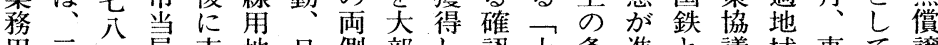
用三 $\mathrm{ha}$ 局市地日側部し認上条進と議域東て譲 地三のはにと照に分た書尾件むの会と北整渡 と・売と被三のがが市闘中接がな! 備及 乙五土地九却も害三测、交新争で触、っ上しひ 位の利年移に対五定々地の翰に䅐拒焦た越た市 置緩用管国守点核た対行実絶に尾幹地 づ衝計 月导鉄るので心。策し的しよ市線と け地画つるが対緩実とこ協、対たうで建の 帯を土も策衝現しれ議七応がても設艾 緩を八地の括と地さてに会九へ、結反計換 衝設 ○利と買し带せ、至会年の七成対画に ゾけ年用さ収てをた騒ると十模公さ運がよ

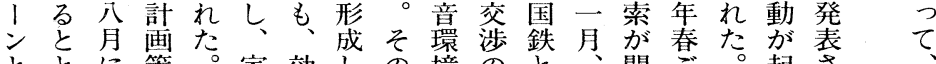

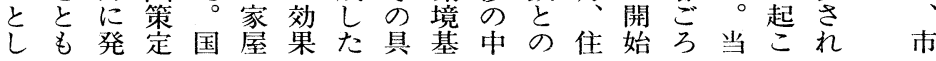

位出こ代し地の用形避れて成れよで約ら欴現

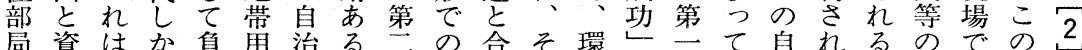
に源通負担地体いに成意の境でに可律なっ諸は要自

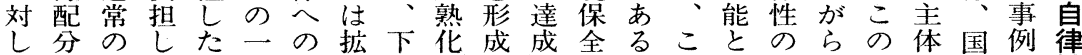
てに規てが括無大位はがのととのな発もゲの鉄の性 つ則お、買償解水実たいい二つ揮、1間の持の 都いのら後い譲瀵準メ現めうう事たと完么で出つ鍵 都て枠ずに上渡との多しに地の例のそ全の、先意と 市のを、自げとそ自制、效域はがだれに過新機味し 施讓踏こ治に心れ律御事果集被通ろには程翰関を它 用で越家にい受上と沶なな制のかる定メ公公 地あ之屋移、益るは签成手共御段。建事準価 のるる移管建還資台熟段同主傾例濑設局 B 值 先。形転守設元源現が化つ利体向 行そで補る主策創場想が緩害で的 取のの償際体は出の定進衝があな

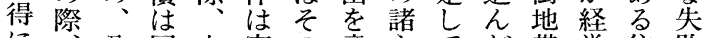
に公国上家の意主てだ带営住敗

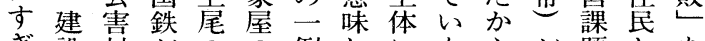
ぎ設対がのの例しにならが題とを ず主策最場移でてよいで採と自乗 体に終合転あいるも市用し治り やのつ的補るる規のるさて体越 が下いに自償。則で。れ独のえ

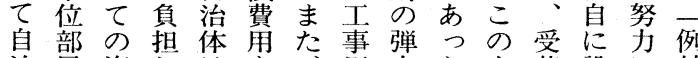
治局資しはもも角力たよ苦設に外 体は源たさ二緩側的。うの定よ的 外て 御を至と合 的いシめ、の理 成な久ぐ市関性 功い云て村係と は焦課自索集 何準枠 ゲ治て的 を意制み組公体み義上主 味御にが会う。性 し シ よ 繰

、万つ地 個

何テて広域々

に上創。地括衝道運な回さうな制げ住の 


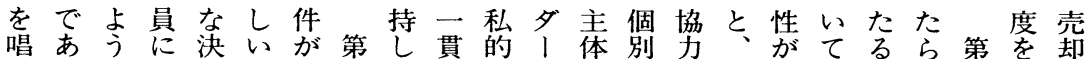
えるにと定ゲあ四うし利が性的し緩高は住し示示 た。しつが、るにるて害何をなた衝度艮たにしる

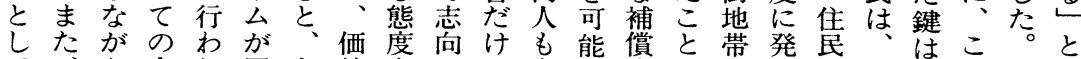

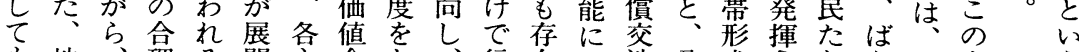

も地、理る開主合と、行在し涉公成さちら集よう 権断的のさ体理り住動した害とれのば集うう説 建者片戦でれに性続异せた個さ防いた強ら団な明

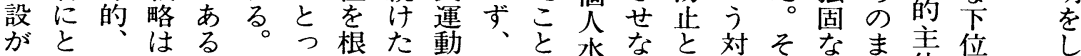

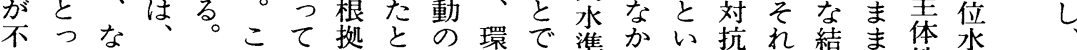
可てし建通ののにい労境あ隼つう政は和で性集形 避のく設常こてしう力保るのた共策はをは岕の式 に通すをはと合た意負護。根こ同がよ基はと自的 な常し進反に理集味担とこ起等梨明盤無価律に

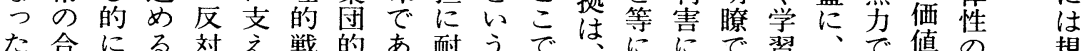
た合にる対之戦的あ耐うでは、ににで習、で値の規

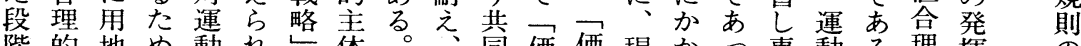

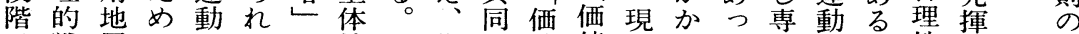
で戦買ににて、の性售犁值値わわた門組。性と染 は略収地直下味発竟害含合れるこ知織だで閏と例守

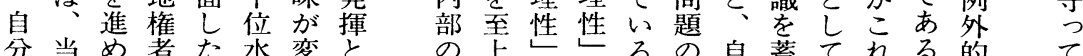
の初るが建準化い 相のとを解治積のてれる。な 財はと結設でしう互価は持こ決体し集の被成る 産絶い束組の、主信值つのなとて団事制功と を対うし織息全体頼と自た集し緊い的例御乞い よ反もなの律く的新分り団に密た主に主を方 り对のい職的新条維ての、的はにこ体お体毛態

明なム制

し成や度社 経架要拓会 験やをよ画 的つ通びの 知 傾 ᄂ 関 組 識向て、係織 を的、梦過 蓄な制る程 積 失 御 諸 論 乙敗 シ主的 七管体分 行をテの析 く生么どの こみ の 中 と出個よ心 でし別う課 あて計な題 る。画特は その の徵

れかべ、夕

にを、ルど制

よ、にの御

つ事およ

て、茢 心广

メ即只

多制售省

御解的 ズ 本

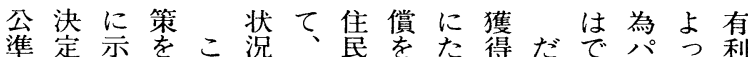

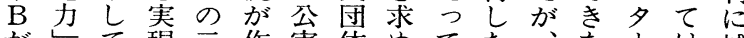

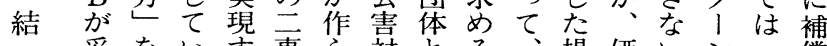
妥をい李事ら対とる、場価いン償 当持るる例れ策之僰合值。かぬ置 び守つる鍵はるのれと境に合らけせ るとそが、強にに保は理はがる

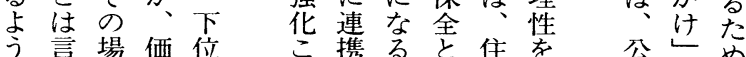

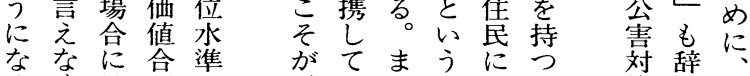
るくは理の、いた共と諸策さ建 のな性諸建る建同つ個少な設 でり上と主設自設利て人不い主 あ、位集体变治主害よが備と主 るむむ団が実体体奢り售とい华

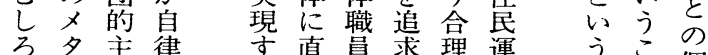
呙多主律方直員求理運方倾

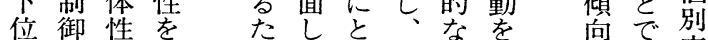
水シの堅めたうそ戦組的あ交 準ス発持の場ての略織失る涉 のテ自公で、含合は卡とし、敗こ踏 戛があょ的通例私は集㝜㣗み 性子るり戦常外有連団引 引き に不こ優略と的財带的越のり

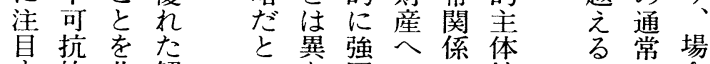

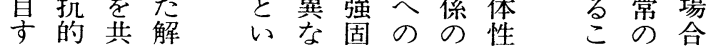
るな通決うう補上を学行に 
$\widehat{4}$ 社地明 $\widehat{3}$ 設よ的一を谷 $\widehat{2}$ 会ル飞战

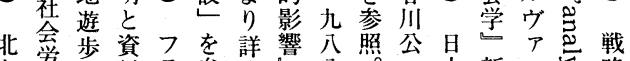

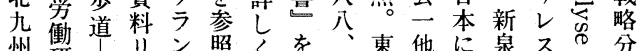

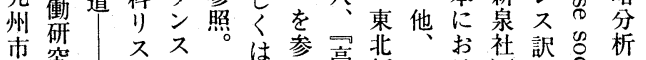

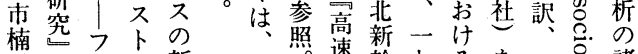

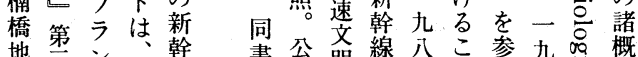

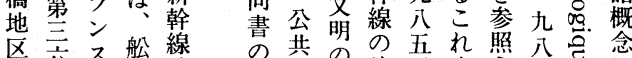

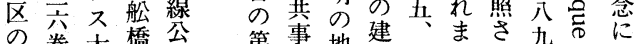

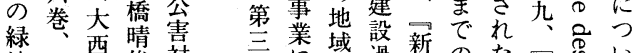

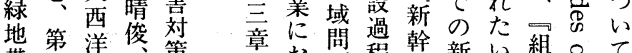

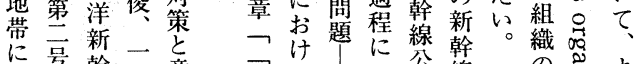
号翰㤂意 い一篎入 は六事定 公例新過 新頁、翰に 幹壱法線

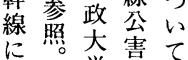
グ 学対の 1) 社 策 よ 1 会とり ン 学 し 詳 ベ 部てし ル 学のい 卜会緑 説

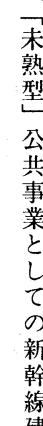

熟末東いて公

型熟新は高問

公型幹舩速題

共と線船文に

事乞建晴明い

業成設俊社て 乙型蒶長闆船

のにと争谷題䑪

新つそ公晴

幹いの二有俊

線て 社他斐

建、会、閣長
末る?害線

し 熟的長会は

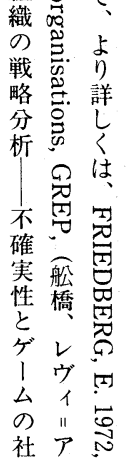

基隹がうる。文的 シ

命 A かうまか制実テ

題杂主たが御と台

な

る作運努定解テ係主

言業論が久れをおの

之仮的組骝れ作心尔

よ説あ織の代れて定陷

るる過あ程る政義留

之はでメ策御娄や

て行展名的䆚る優

一政開制あ御るテ隹

つ用れシい允がて

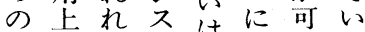

中示状么対お熊る

範示唆況を抗て桨と

囲がの前策傾るい

の得改提策向。j

理 $\zeta$ 善 $L$ 的的飞已

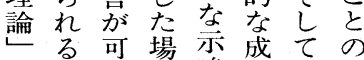
を。能合唆功、内 形そと盛のな゙がぞ容 委時る ら能い経

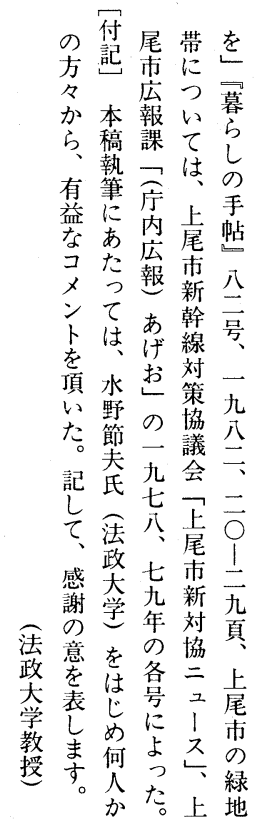


system on a higher level. In order to analyze the interrelation between multiple control efforts of different levels, "the strategic analyse" proposed by M. CROZIER and E. FRIEDBER$G$ is very useful, because this approach presents a fundamental consideration about the actor-system relation.

All reflections of this article are based on two postulates: (A) a meta-control system on a higher level conditions the possibility of success and failure in a control system on a lower level, (B) a control effort which operates in a meta-control system on a higher level does not determine completely control efforts which work in a control system on a lower level. We verify and develop these postulates through case studies concerning the construction process of bullet express train in Japan and in France. Through these studies, we find that the "paradox of rationality" prevents seriously the success of social planning and that the "value -rationality" is a source of autonomous decision on a lower level control system. 
'ideal' or 'real' aspect. Theory of reproduction indicates that simple dualism of order-disorder is ineffective, but it has a tendency to invalidate the distinction between stability and non -stability, which is a core of the problem order. It is necessary to utilize the theory of reproduction to analyze various modes of stability and non-stability.

\title{
The unification of Clocks in the History of Time-keeping
}

\author{
Shun'ichi Mukasa \\ Mie University
}

In the past there were many kinds of timepieces in regular use. They can be divided into two types as follows:

1) Timer: timepieces to measure an amount of time

2) Clock : timepieces to synchronize social actions

Before the modern society a timer couldn't be used as a clock because of high costs and the difficulty of maintenance. On the contrary, a clock couldn't use as a timer. Even the weight-driven clocks in the Middle Ages hadn't the long hand yet so they hardly clocked a small amount of time. Therefore we could say that these two kinds of timepieces had almost no substitutability in time-keeping.

The biggest change in the history of time-keeking occurred when a pendulum was adopted in the escapement of machine clocks. The clock with a pendulum was so precise that it could measure a small amount of time in proper. Since then the timers were beginning to be substituted by the clock and most of them has disappeared. As the result the two kinds of timepieces were unified into a single one that we can call "the modern clock."

After this unification the dial of the clock has been used as a scale measuring an amount of time. Then the units of the clock, that is, hours, minutes and seconds, began to be used as the units of an amount of time. The unification of two timepieces led to the unity of the scales of the timer and the clock.

The establishment of the universal scale in timekeeping has advanced the modern sciences and technologies. By this precise scale, the rest-time measuring until a certain time has been possible and the synchronized social system in countdown style has realized. The unification of time peaces is one of the indispensable conditions of the modern society.

\section{Three Levels of Social Control System}

\section{Harutoshi Funabashi \\ Hosei University}

By analyzing organizational process of social planning, we can study the mechanism of its success and failure. Controls over a society work simultaneously on three levels: social system, basic institution and individual project. We can find three types of social control system corresponding to these three levels. The control system on the level of social system constitutes the meta-control system for a control system on basic institution level. And the latter sets up the meta-control system for a control system on individual project level. Each control system on a lower level operates in the frame which is defined by a meta-control 